\title{
Active Learning: Using Bloom's Taxonomy to Support Critical Pedagogy
}

\author{
Sirous Tabrizi, Glenn Rideout \\ University of Windsor \\ Canada
}

\begin{abstract}
Many education systems use a primarily passive approach to learning. So that students may have a deeper and more meaningful learning experience, educators can use an active learning approach. This approach attempts to engage students at higher levels of thinking so that they are more interested in, better engaged with, and understand better the course material. Critical pedagogy, on the other hand, focuses on empowering students to become agents of social change for greater equity and justice. Although critical pedagogy is often seen as giving education a political goal, it is actually a good concrete example of applying active learning principles in a classroom. To better understand the relationship between active learning and critical pedagogy, this paper will explore how Bloom's taxonomy can describe the activities involved in active learning and how those activities are necessary for critical pedagogy.
\end{abstract}

\section{Introduction}

These Many education systems follow a traditional method in their learning process, which means a teacher teaches in his/her classroom and the students are taught. The teacher talks and the students listen, and sometimes they can ask questions which are related to syllabus; the teacher is the subject and the students are mere objects [5]. In this traditional education system, student at all levels may achieve the passive part of learning, which only requires techniques such as lecturing, assigned textbook readings, and watching videos or demonstrations. However, in active learning, students are required to engage in higher-order thinking tasks (e.g., analysis, synthesis, evaluation, reflection) through various activities (e.g., see [3]). These higher-order tasks are best described using Bloom's taxonomy, and are the upper levels of this taxonomy. For developing active learning the education system needs a special kind of pedagogy like critical pedagogy. As McLaren asserts, the major concern of CP is the centrality of politics and power in our understanding of how schools work [27]. To Freire, education should lead to transforming action and it is a political praxis which constantly serves to liberate humans [10]. Good teaching should aim at political transformation for the purpose of justice [6]. Thus, this paper will discuss how critical pedagogy can help to use an active learning approach to teaching, using Bloom's taxonomy as a tool for analyzing whether the activities involved are achieving the goals of both.

\section{Literature Review}

In this section we will discuss three topics: active learning, critical pedagogy, and Bloom's taxonomy. This section is meant to provide background information on these topics.

\subsection{Active learning}

Active learning (AL) is a method for engaging students in higher-order thinking tasks (e.g., analysis, synthesis, evaluation, reflection) through various activities [5] so that students achieve more than merely the passive part of learning (see Figure 1). For example, instead of listening to a lecture on some topic students would discuss the topic with each other, imagine how could be used in practice and provide concrete examples, and give a presentation on these examples. This could be done individually, but often it is done in groups so that multiple students can be discussing together the same topic, using their own examples, ask questions during the presentations, and so on. AL requires much more effort from both teachers and students. However, there are many inclass activities that are obvious examples of active learning: group discussions of material, giving feedback and doing reflection on one's own work, peer evaluation, giving presentations on material. As such, classroom management becomes quite important; it is necessary for teachers to manage the students so that these more active exercises can be promoted and effectively conducted.

A teacher using an AL approach needs to read the current state and quality of the class, so as to promote the appropriate next set of discussions. This can be done through effective questions, discussions, and thinking -- whereby a teacher attempts to solve various questions such as [12]: What should questions 
require from listeners? What responses should be allowed? How can discussion resulting from a question be limited and focused? How can thought and attention be directed to the appropriate topic? The deeper and richer that students are able to think, the deeper and richer will be their learning. As such, students can be encouraged and supported in becoming better thinkers and will become better learners in the process. Better thinking can result from asking better questions, having a diversity of viewpoints (e.g., diversity of backgrounds or worldviews of students), and promoting a variety of opinions and positions on some topic [21]. Such variety can help to engage students' minds more deeply. Teachers may also consider the upper portions of Bloom's Taxonomy, to develop questions for discussion. Since open-ended questions can promote a various responses, this type of question is usually more supportive of AL [7]. Creating an environment that promotes a creative, expansive, and open style of thinking, critiquing, and questioning can also create strong possibilities for AL [31]. Although teachers are often the one asking questions, students can be asking questions as well and creating an environment where students are able to ask such questions will also help to deepen the learning that occurs.

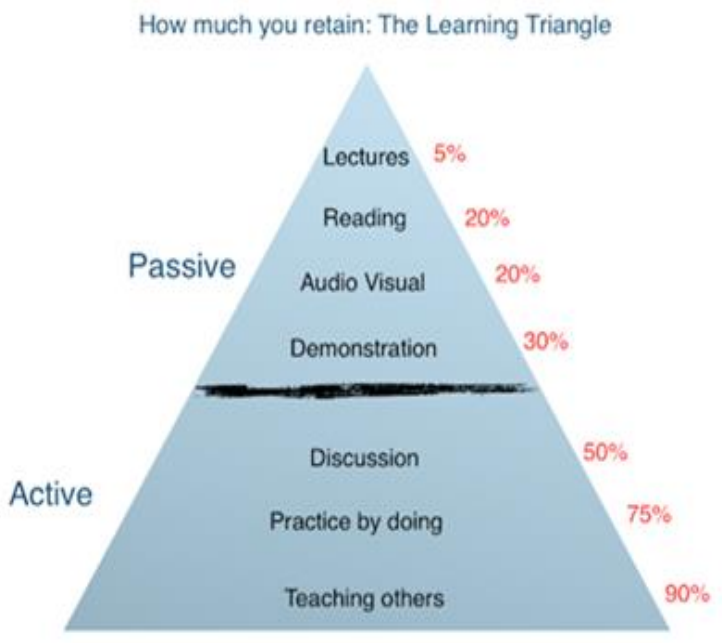

Figure 1. Diagram showing the difference between amounts learned through different means of instruction (from [5])

\subsection{Critical pedagogy}

Critical Pedagogy (CP) is an approach to language teaching and learning concerned with transforming relations of power which are oppressive and which lead to the oppression of people [20]. As such, it tries to humanize and empower learners. In a more specific sense, Ira Shor defines CP as: "Habits of thought, reading, writing, and speaking which go beneath surface meaning, first impressions, dominant myths, official pronouncements, traditional clichés, received wisdom, and mere opinions, to understand the deep meaning, root causes, social context, ideology, and personal consequences of any action, event, object, process, organization, experience, text, subject matter, policy, mass media, or discourse" ([30] p. 129).

A major purpose underlying $\mathrm{CP}$, then, is to critique and challenge the way in which schools affect the political and cultural life of students; this can be done through analyzing, critiquing, and discussing the power that schools have over the critical thinking abilities and activist attitudes that students develop [9]. Furthermore, teachers who use a CP approach need to realize their role in empowering and transforming students, so that teachers can become agents of change as well instead of perpetuating injustice and inequity [27]. Thus, the major goals of $\mathrm{CP}$ are raising awareness of, and working to prevent and fight against, discrimination against people [14]. It is a direct challenge to any form of domination, oppression, or subordination against others.

The approach of $\mathrm{CP}$ is most strongly associated with the Brazilian educator and activist Paulo Freire, who described the role of education as being completely connected to being humanized social agents of positive change in the world [11]. This view of education as being intimately linked to political and power struggles is quite different from traditional perspectives of education, which claim to be neutral in such struggles and detached from political ideologies [9]. In many ways, $\mathrm{CP}$ is a response by researchers and practitioners in education to inequalities and oppressive power relations within the education system [22]. Before CP, there was a push to focus on larger socio-historical and political forces within the school itself (e.g., [18]). However, since many classrooms are so detached from the historical and social conditions that could be discussed that it was necessary to explicitly focus on such things through CP [32]. Thus, CP needs to directly address the potential cultural and political influences a school can have through describing, legitimizing, and challenging the cultural experiences of the historical and current social reality of the students in a way that students learn to criticize, form and adjust their own social reality [9].

$\mathrm{CP}$ operates primarily through posing problems, and questioning issues in students' lives, such that students learn to think critically about themselves and develop a consciousness of their own life conditions and the steps needed to improve the surrounding society [14]. Since students can share information about their own experiences, such a method allows students to speak with more authority [5]. This is usually connected to media literacy. In $\mathrm{CP}$, students can be taught to become aware of, sensitive to, and capable of identifying representations of race, ethnicity, gender, sexuality, class, and other cultural differences within various forms of media [19]. As a result, students can become better able to identify 
when people are trying to use various forms of media (video, text, photos, etc.) to oppress, marginalize, or exert power over other groups and can thus avoid or fight against it. In essence, CP shows how audience, voice, power, and evaluation actively create particular relationships -- between teachers and students, classrooms and communities, institutions and society -- such that the relationships between knowledge, authority, and power become more readily noticeable [13]. Thus, through analyzing media, CP provides students with the tools to better themselves and strengthen democracy, to become empowered and able to resist manipulation and domination [19].

For CP to be effective, students must be able to discuss, debate, question, and critique the course material. This is necessary for them to learn how to identify the underlying power relationships and influence within the material. In addition, students need to be able to identify such influence on their own, without relying upon a teacher to indicate what the 'correct answer' might be with respect to influence. Otherwise, students only learn how to identify the power relationships or imbalances that other experts (i.e., the teacher) have previously identified; this will not help students in circumstances where they might need to challenge the power relationships of the majority since the same majority will likely be the experts they have learned to follow.

\subsection{Bloom's taxonomy}

Bloom's taxonomy refers to a commonly used framework created by Bloom and colleagues [2] to organization different levels of expertise with respect to measurable student outcomes. The taxonomy was later revised, changing some of the terminology and elaborating what was meant by the different levels. Furthermore, the ideas in Bloom's taxonomy can be applied to multiple domains and not simply knowledge. As a result, taxonomies were developed for multiple domains: cognitive or knowledge-based goals, psychomotor or skill-based goals, and value or affective-based goals [8]. There are six major levels in Bloom's taxonomy for the knowledge-based domain: remembering, understanding, applying, analyzing, evaluating, and creating (see Figure 2). These levels lie along a continuum from simple (remember) to complex (create), and from concrete to abstract. The level of expertise is organized in terms of increasing complexity, such that higher levels of expertise involve more sophisticated measurement of student outcomes. For example, the low-level of 'remembering' can be measured through a simple multiple-choice test, but the higher-level of 'evaluating' would require longer written responses, presentations, or oral discussions in order to measure the outcomes.

\section{The New Version of Bloom's Taxonomy}

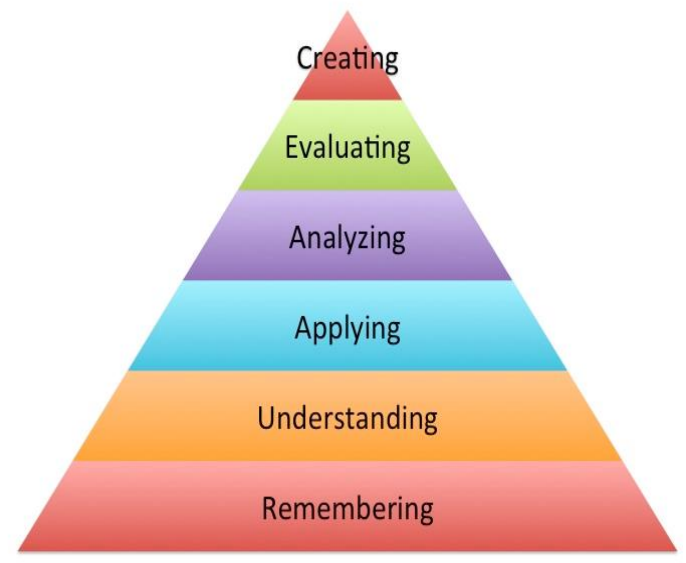

Figure 2. Diagram showing the knowledge-based categories of Bloom's taxonomy (from [1])

Bloom's taxonomy instructors to identify the level of expertise of their students, examine the common activities on each level, and determine how best to incorporate those activities into their classes. Often the activities are listed as verbs that could be included in questions asked of students or used to develop activities (see Tables 1 and 2 below for examples). The verbs in the higher levels of the taxonomy are more open-ended and require more creativity to answer. As such, those levels tend to be more associated with an AL approach [7]. These questions help to elicit behaviors appropriate with AL, but it is also important for teachers to create an environment that promotes the creative and open form of questioning and thinking appropriate for AL. In other words, it is not enough for a teacher to simply ask questions for the desired taxonomic level, the teacher also needs to create an environment conducive to students asking those questions too. Furthermore, AL requires engaging students with techniques other than lectures and teacher-driven presentations. However, using other techniques does not simply mean a higher level in the taxonomy will be reached. For example, students could perform a group study of material and give a presentation to their peers. Both the group study and peer-presentations are examples of techniques associated with AL, but the topic of their study could be questions reminiscent of the lower levels in Bloom's taxonomy. The students would need to be given a study topic that engages a higher level, such as 'evaluate how well authors $\mathrm{X}$ and $\mathrm{Y}$ argue their perspectives on this topic' instead of 'describe the position taken by authors $\mathrm{X}$ and $\mathrm{Y}$.' By looking at Bloom's taxonomy then, teachers can come up with questions to guide the AL techniques they use in the classroom. 
Table 1. Examples for Bloom's knowledge-based taxonomy (adapted from [33])

\begin{tabular}{|c|c|c|}
\hline Level & Verbs & Example questions to measure student outcome \\
\hline Remembering & $\begin{array}{c}\text { Recall or recognize terms, ideas, procedure, } \\
\text { theories, etc. }\end{array}$ & What is a learning organization? \\
\hline Understanding & $\begin{array}{c}\text { Translate, interpret, or extrapolate ideas, } \\
\text { but not see larger implications or transfer to } \\
\text { other situations }\end{array}$ & $\begin{array}{c}\text { How does a learning organization differ from } \\
\text { other organizations? }\end{array}$ \\
\hline Applying & $\begin{array}{c}\text { Apply abstractions, general principles, or } \\
\text { methods to specific concrete situations }\end{array}$ & $\begin{array}{c}\text { What is one thing that would need to change } \\
\text { for an organization to become a learning } \\
\text { organization? }\end{array}$ \\
\hline Enalyzing & $\begin{array}{c}\text { Separate a complex idea into its parts and } \\
\text { develop an understanding of the } \\
\text { organization and relationship between those } \\
\text { parts }\end{array}$ & $\begin{array}{c}\text { For a learning organization to function, what is } \\
\text { the relationship like between leaders and } \\
\text { subordinates? }\end{array}$ \\
\hline Creating & $\begin{array}{c}\text { Use multiple sources to integrate complex } \\
\text { ideas into a new and meaningful concept, } \\
\text { subject to the given constraints }\end{array}$ & $\begin{array}{c}\text { If a school was to become a learning } \\
\text { organization, is there anything special or } \\
\text { different that needs to be done? If so, what? }\end{array}$ \\
\hline & $\begin{array}{c}\text { Make a judgment of ideas or methods using } \\
\text { external evidence or self-selected criteria, } \\
\text { substantiated by observations or informed } \\
\text { rationalizations }\end{array}$ & $\begin{array}{c}\text { To determine if your school is a learning } \\
\text { organization what are some things you would } \\
\text { need to measure? }\end{array}$ \\
\hline
\end{tabular}

Table 2. Examples for Bloom's skill-based taxonomy (adapted from [33])

\begin{tabular}{|c|c|c|}
\hline Expertise Level & Description of level & $\begin{array}{l}\text { Example questions to measure student } \\
\text { outcome }\end{array}$ \\
\hline Perception & Use sensory cues to guide actions & $\begin{array}{c}\text { Using only observation, how can you tell if a } \\
\text { bicycle is safe to ride? }\end{array}$ \\
\hline Set & $\begin{array}{c}\text { Demonstrate a readiness to take action to } \\
\text { perform some task }\end{array}$ & $\begin{array}{l}\text { Describe the steps you would take to start } \\
\text { riding a bicycle along a flat path. }\end{array}$ \\
\hline Guided Response & $\begin{array}{l}\text { Show knowledge of the steps required to } \\
\text { complete the task }\end{array}$ & $\begin{array}{l}\text { Describe how your actions will move you and } \\
\text { the bicycle along the path. }\end{array}$ \\
\hline Mechanism & $\begin{array}{l}\text { Perform the task in a somewhat confident, } \\
\text { proficient, and habitual manner }\end{array}$ & $\begin{array}{l}\text { Ride the bicycle three times around a flat } \\
\text { track. }\end{array}$ \\
\hline Complex Overt Response & $\begin{array}{l}\text { Perform the task in a confident, proficient, } \\
\text { and habitual manner }\end{array}$ & $\begin{array}{l}\text { Ride the bicycle three times around a bumpy } \\
\text { and uneven track. }\end{array}$ \\
\hline Adaptation & $\begin{array}{l}\text { Perform the task as above, but can also } \\
\text { modify actions to account for new or } \\
\text { problematic situations }\end{array}$ & $\begin{array}{l}\text { Ride the bicycle from the school to a store, } \\
\text { pick up a dozen eggs, and bring them back to } \\
\text { the school. }\end{array}$ \\
\hline Organization & $\begin{array}{l}\text { Create new tasks that incorporate previously } \\
\text { learned ones }\end{array}$ & $\begin{array}{l}\text { Describe what changes you need to make to } \\
\text { your daily routine to bike to and from school } \\
\text { every day. }\end{array}$ \\
\hline
\end{tabular}

\subsection{Metacognition}

Metacognition is a rather nebulous term, since it has different definitions and uses different terms to refer to roughly the same phenomenon or parts of that phenomenon (e.g., executive control, meta-memory, self-regulation) [16]. In learning, it refers to a function of higher-order thinking that actively monitors, regulates, and controls the cognitive processes involved in learning [34]. Some examples of activities to which the term metacognition typically refers 
include planning a solution to some problem and evaluating how complete a task may be.

Metacognition is important because of its relationship to increased success in learning (e.g., [15]). In particular, by having increased training in metacognitive strategies, students tend to be more successful in their learning and benefit more from their instruction [34]. There are different ways to train students in metacognition, or rather training students how to use different metacognitive strategies, the most effective seems to be providing metacognitive knowledge, providing opportunities to practice metacognitive strategies, and assist students evaluate the effectiveness of their approach [16]. Metacognitive knowledge is the knowledge that a student gains about cognitive processes to help them control those processes [17]. This knowledge can be focused on one of three variables: person, task, and strategy [17]. By having knowledge of person variables, a student understands better how they learn and process information, what methods work best for them to learn better, and typical obstacles that impede analyzing and processing information [17]. In contrast, knowledge of task variables includes details of a task itself, the steps needed to complete it, and how those steps are interconnected [17]. By having knowledge of strategy variables though, a student understands possible cognitive and metacognitive strategies that could be employed to assist with learning or completing a task [17].

Cognitive strategies include methods of analyzing data while metacognitive strategies focus more on the individual's understanding of that data (selfreflection, self-questioning). For example, a task could be to identify key topics within a text. A student could use certain cognitive strategies (such as dividing the text into smaller chunks and summarizing those chunks) to identify main topics. Then, the student could use a metacognitive strategy of selfreflection to determine whether the identified topics are the ones required for the task and whether they have summarized the text appropriately. As another example, a student could be taking a math exam, realize that they have difficulty with word problems (person variable knowledge), see that this exam includes both word and non-word problems (task variable knowledge), and decide to solve the nonword problems first so that more of the exam can be finished in the short time available (strategy variable knowledge).

As metacognition improves learning and enables stronger self-reflection, its promotion as part of a course is consistent with the goals of active learning and critical pedagogy. Since metacognitive ability can be improved through instruction, it also makes sense to include it as part of active learning material; not only can students use instruction about metacognition to improve the quality of their learning but they can also improve in their ability to use metacognition in general.

\section{Discussion}

$\mathrm{CP}$ is not meant to replace or abandon welldeveloped teaching methods, but to add a critical quality to both textbooks and instruction [26]. It is not meant to be a single-strategy pedagogy for empowerment, but instead is meant to be adapted and used in response to local context and needs [23]. In this sense then, CP is a theory and practice of helping students to develop a critical approach towards life [24]. In many ways then, CP is an example of AL in how teachers must engage students. Both require a more active and direct engagement of students, using collaborative, cooperative, and problem-based learning [5]. $\mathrm{CP}$ is highly political and has a very specific goal in mind [6]. AL, in contrast, is a more generic approach to learning that can be used regardless of the goal and content. However, even if a teacher is not interested in the political goal of CP, any application of $\mathrm{CP}$ faces much the same problems as any application of AL [24].

For instance, one goal of CP is to remove one-way relationships between student and teacher, where a student merely listens and is assumed to know nothing while the teacher has the necessary knowledge and does all the talking [5]. Although the removal of this relationship is not part of AL, the effect is the same: requiring students to become active agents of their own learning, sharing their own opinions, and discussing with other students such that the role of teacher is often shared to a lesser degree among the students themselves. However, in practice this can be very difficult to do. Students may feel uncomfortable being asked their opinion or describe previous experiences, as well as with ambiguity in that there may not be a single "correct" answer to a particular question or topic [25]. This can be handled through practice, in that as students are regularly and frequently encouraged to participate in this manner they are able to adapt [5]. However, the teacher then has the challenge of supporting students so that their opinions are informed, their views have good support (either empirical or rational arguments), and they can constructively handle ambiguity, a diversity of opinions, and challenges to their opinions [5].

Furthermore, it is useful to consider the conditions that lead students to engage in critical thinking, one of the necessary components of critical pedagogy. First, students need to develop at least skills in critical thinking, and understand the uses, benefits, and limitations of these skills [28]. Consider, for example, methods of analysis, which involve removing an object of study from its context to focus attention on it and understand its components. Although useful information is gained from this method, information 
is also lost since the object's relationships in its original context are not included in the analysis.

Second, students must be able to think outside their conventional framework of understanding and any framework given within a classroom [28]. In other words, students need to develop the capacity to think differently than others. One aspect of this for $\mathrm{CP}$ in particular is the need to think outside the ideologies and messages used for power struggles and manipulation. If students cannot think outside the framework created by those messages then they cannot analyze, critique, and evaluate how those messages affect well-being of others. From the perspective of $\mathrm{CP}$ then, students cannot learn to act for better social change if they are unable to think outside the constraints the current system has placed upon them. However, for AL in general, this ability to think differently helps students to realize that any teaching environment has its own set of assumptions, messages, and goals [28]. It is not enough to simply critique a specific framework, as in the case of $\mathrm{CP}$, but to learn how to critique any framework. Otherwise, students cannot reach the full potential desired from AL.

Although these two concerns are important, there needs to be an environment created conducive to building and using them. In particular, thinking differently requires an openness to, and comfort with, thinking in deeply challenging circumstances, circumstances that usually contain high degrees of tension [28]. Thus, any education environment needs to nurture this openness and comfort in addition to allowing challenging tension to be created. The different and opposing views need not be real (i.e., they could be thought experiments for the purpose of the class), but they must be taken seriously and respected as a viable alternative. As part of this environment, teachers use less authority than teaching without $\mathrm{CP}$ or AL since the students have the authority of their own opinions and views [5]. At the same time, traditional assessment measures are inappropriate for a CP classroom, but that is often a result of using only the lower two or three levels of Bloom's taxonomy. For example, if students are engaged in debates, group work, and cooperative learning then it does not make sense to evaluate them in a typical competitive manner [5]. Thus, evaluation should involve higher levels of Bloom's taxonomy such as using creative projects and peer-evaluation; students can learn to critique each other's work, offer constructive criticism, and generate rubrics for each other [5]. Such involvement in the evaluation process also creates transparency in the evaluation process and the expectations of students, and helps students to better see the power relationships that occur within the classroom itself.

Lastly, students must realize how their own views and assumptions are part of an existing framework, and have arisen from a particular cultural and temporal context [28]. Such a realization eventually leads to the deeper realization that one's views and assumptions can be continually challenged, and are always open to improvement, revision, and adaptation. This last realization is difficult to maintain without social reinforcement, through regular exposure to others with contrasting views. Thus, a class environment for this critical approach requires plurality of views, and tolerance and respect of these differences, to ensure that students develop a habit of reflecting on their own framework [28].

Furthermore, it is not necessary to subscribe to the political aspects of CP to adapt its methods to other contexts. As has been discussed, just taking a critical approach is already difficult to achieve and beyond what typically occurs in a classroom. Fobes and Kaufman discuss the potential problem of using CP in a classroom where students resist the desire to take a progressive social activist role [5]. In such a case, it may be necessary to engage in dialogue with such students over the purpose of education and how, even if they are not interested in the political angle of $\mathrm{CP}$, they are still actively working towards change in society through their desire or intention to use their education to further a career.

Since AL refers to students actively seeking out their own learning, instead of waiting for knowledge to be given to them, the approach to AL in a classroom will differ depending on the age, developmental stage, and interests of each student [29]. AL does not necessarily require students to physically move around, but it does require teachers to have a general sense of what opportunities could be created for students. One method for creating such opportunities is to use Bloom's taxonomy to inform the writing of educational objectives [29]. Teachers may already be in the habit of writing such objectives, to help qualify what students are expected to learn after each lesson and course. The main difference here is to look at the verbs used in Bloom's taxonomy so that terms at top three levels are used in these objectives.

For example, a typical objective might be "list causes of World War I". This works well with the bottom level of Bloom's taxonomy (remember), but is not an example of encouraging an AL approach. However, consider the objective "defend the reasons given by the Great Powers for entering World War I." This second objective requires significantly more effort on the part of the student, and lends itself to group activities as well as discussing and critiquing different opinions. When combined with the complementary objective of "critique the reasons given by the Great Powers for entering World War I," students would now be expected to know these reasons well enough that they could both attack and defend them. The teacher would need to create an environment in which such arguments could occur in a safe, logical, and respectful manner. Since the verbs "defend" and "critique" are both associated with the 
fifth level of Bloom's taxonomy (evaluate), that simple change not only facilitated an AL approach for deeper and richer engagement with the course material but also created an opportunity for a critical learning or CP approach to this topic.

Taking a critical approach to education involves a high degree of collective questioning, criticism, and creativity. It is always social in nature, since these activities arise from interactions with others and the differing view they hold [4]. Although the verbs in Bloom's taxonomy need not be social in nature, an opportunity to express them in a social setting can usually be done. In the simple example on World War I above, students could write individual reports to solve those objectives or they could engage in debates with other students and rotate between representing the views of different Great Powers. Both are ways in which higher levels of Bloom's taxonomy could be used in a classroom, but only the social example was consistent with an AL and CP approach.

\section{Conclusion}

For educators interested in promoting a deeper, richer, and more meaningful education the theory of $\mathrm{AL}$ is likely an appealing one. However, the increasing popularity of $\mathrm{CP}$ may encourage others to take their approach to education. As this paper has discussed though, the two approaches are very similar and $\mathrm{CP}$ can be seen as an application of AL in a specific context: that of empowering students to become agents for positive social change. However, if that context is too political for teachers, the broader goal of having a critical approach to life is already consistent with both CP and AL. Thus, teachers would benefit from creating an environment with the interdependent conditions of communicative opportunities, challenging but yet supportive social relations, and contexts of difference that enable students to think outside a standard framework [28]. This requires a host of other AL strategies, such as group work, presentations, group discussions, question sessions, and so on. However, it is easier for teachers to think of strategies to use when looking at the verbs for the higher levels of Bloom's taxonomy. For educators looking to find a way of implementing an AL approach in their classroom, it may be beneficial to use the more concrete example of $\mathrm{CP}$ as a starting point and link it to Bloom's taxonomy.

\section{References}

[1] Anderson, L.W., D.R. Krathwohl, P. Airasian, K. Cruikshank, R. Mayer, P. Pintrich, ... and M. Wittrock, $A$ taxonomy for learning, teaching and assessing: A revision of Bloom's taxonomy, New York, Longman Publishing, 1992.
[2] Bloom, B., M. Englehart, E. Furst, W. Hill, and D. Krathwohl, Taxonomy of educational objectives: The classification of educational goals, Handbook I: Cognitive domain, New York, Longmans, 1956.

[3] Bonwell, C.C., and J.A. Eison, Active Learning: Creating Excitement in the Classroom. 1991 ASHE-ERIC Higher Education Reports, ERIC Clearinghouse on Higher Education, The George Washington University, 1991.

[4] Burbules, N.C., Dialogue in Teaching: Theory and Practice, New York, Teachers College, 1993.

[5] C. Fobes, and P. Kaufman, "Critical pedagogy in the sociology classroom: Challenges and concerns", Teaching Sociology, Vol. 36 (January), pp. 26-33, 2008.

[6] C. Joldersma, "The tension between justice and freedom in Paulo Freire's epistemology", Journal of Educational Thought, Vol. 35, Issue 2, pp. 129-148, 1999.

[7] D. Huinker, and J.L. Freckmann, "Focusing conversations to promote teacher thinking", Teaching Children Mathematics, Vol. 10, Issue 7, pp. 352-357, 2004.

[8] D.R. Krathwohl, "A Revision of Bloom's Taxonomy: An Overview”, Theory Into Practice, Vol. 41, Issue 4, pp. 212218, 2002. DOI: 10.1207/s15430421tip4104_2

[9] Darder, A., R. Torres, and M. Baltodano, The Critical Pedagogy Reader, RoutledgeFalmer, New York NY, 2002.

[10] Freire, P., The Politics of Education: Culture, Power, and Liberation, Bergin Garvey, 1985.

[11] Freire, P., Pedagogy of the Oppressed, Continuum Publishing, 1970.

[12] Fusco, E., Effective questioning strategies in the classroom: A step-by-step approach to engaged thinking and learning $K-8$, Teachers College Press, 2012.

[13] Giroux, H.A., Pedagogy and the Politics of Hope: Theory, Culture, and Schooling. A Critical Reader, Westview Press, 1997.

[14] H. Gor, "Critical Pedagogy, Pedagogy for Human Rights Education", International Symposium on Human Rights Education and Textbook Research, Kibbutzim college of Education, 2005.

[15] J. Borkowski, M. Carr, and M. Pressely, "Spontaneous strategy use: Perspectives from metacognitive theory", Intelligence, Vol. 11, pp. 61-75, 1987.

[16] J.A. Livingston, "Metacognition: An overview", 1997. Retrieved from:http://gse.buffalo.edu/fas/shuell/cep564/ metacog.htm, (Access date: 2 April 2015).

[17] J.H. Flavell, "Metacognition and cognitive monitoring: A new area of cognitive-developmental inquiry", American Psychologist, Vol. 34, pp. 906-911, 1979.

[18] J.K. Hall, "Creating our worlds with words: A sociohistorical perspective of face-to-face interaction", Applied Linguistics, Vol. 16, pp. 206-232, 1995 
[19] Kellner, D., Multiple Literacies and Critical Pedagogies in Revolutionary Pedagogies - Cultural Politics, Instituting Education, and the Discourse of Theory, P.P. Trifonas, Editor, Routledge, 2000.

[20] Kincheloe, J.L., Critical Pedagogy Primer, Peter Lang Publishing, 2005.

[21] Kustra, E.D.H, and M.K. Potter, Green guide (9). Leading Effective Discussions, Society of Teaching and Learning in Higher Education, London Canada, 2008.

[22] L. Kessing-Styles, "The relationship between critical pedagogy and assessment in teacher education", Radical Pedagogy, Vol. 5, Issue 1, 2003. Retrieved from http://radicalpedagogy.icaap.org/content/issue5_1/03_keesi ng-styles.html, (Access date: 3 March, 2016).

[23] Luke, C., and J. Gore (Eds.), Feminisms and Critical Pedagogy, Routledge, New York NY, 1992.

[24] M.J. Riasati, and F. Mollaei, "Critical Pedagogy and Language Learning", International Journal of Humanities and Social Science, Vol. 2, Issue 21, pp. 223-229, 2012.

[25] M. Weimer, "Critical Pedagogy Brings New Teaching and Learning Challenges", Faculty Focus, Magna Publications, 2009. Retrieved from http://www.facultyfocus.com/articles/teaching-andlearning/critical-pedagogy-brings-new-teaching-andlearning-challenges/, (Access date: 9 August, 2015).

[26] Malott, C., and B.J. Porfilio, Critical pedagogy in the twenty-first century: A new generation of scholars, IA Press, 2011.

[27] McLaren, P., Life in School: An Introduction to Critical Pedagogy in the Foundation of Education, Longman, 1989.

[28] N. Burbules, and R. Berk, "Critical Thinking and Critical Pedagogy: Relations, Differences, and Limits," Critical Theories in Education, T.S. Popkewitz, and L. Fendler, Editors, New York, Routledge, 1999. Retrieved from: http://faculty.education.illinois.edu/burbules/papers/ critical.html, (Access date: 8 November, 2015).

[29] S. Fleming, "Fitting Bloom's Taxonomy with Active Learning," Bright Hub Education, 2012, retrieved from http://www.brighthubeducation.com/teaching-methodstips/23494-how-active-learning-and-blooms-taxonomyrelate-to-one-another/, (Access date: 14 February, 2015).

[30] Shor, I., Empowering Education: Critical Teaching for Social Change, University of Chicago Press, 1992.
[31] Senge, P.M., The fifth discipline. The Art \& Practice of the Learning Organization, Doubleday, New York NY, 2006.

[32] T. Okazaki, "Critical consciousness and critical language teaching", Second Language Studies, Vol. 23, Issue 2, pp. 174-202, 2005.

[33] University of North Carolina (UNC) at Charlotte, "Bloom's Taxonomy of Educational Objectives," 2017, Retrieved from http://teaching.uncc.edu/bestpractice/goals-objectives/blooms-educational-objectives, (Access date: 15 July, 2016).

[34] Van Zile-Tamsen, C.M., Metacognitive self-regualtion and the daily academic activities of college students, Unpublished doctoral dissertation, State University of New York at Buffalo, 1996. 